\title{
ANALISIS YURIDIS PENGGUNAAN PERJANJIAN PENGIKATAN JAMINAN FIDUSIA DAN KUASA (PPJF) TERHADAP MESIN YANG MASIH DALAM PEMESANAN MENGGUNAKAN LETTER OF CREDIT
} (LC)

Oleh :

\author{
Agus Andrianto \\ Email : agus_andrianto20@yahoo.com \\ Universitas Narotama Surabaya
}

\begin{abstract}
Abstrak
Kredit atau pembiayaan berdasarkan prinsip syariah yang diberikan oleh bank mengandung risiko, sehingga dalam pelaksanaannya bank harus memperhatikan asas-asas perkreditan atau pembiayaan berdasarkan Prinsip Syariah yang sehat. Sebagai lembaga intermediary dan seiring dengan situasi lingkungan eksternal dan internal perbankan, saat ini sedang mengalami perkembangan pesat. Bank dituntut untuk lebih fleksibel dalam memberikan pembiayaan / kredit dengan menerima jaminan yang masih akan ada dikemudian hari. Salah satunya yaitu melalui kegiatan kredit / pembiayaan berdasarkan prinsip syariah lewat instrumen yang dikenal dalam transaksi perdangan internasional adalah Letter of Credit ("L/C"). L/C adalah suatu jaminan pembayaran yang pasti dari issuing Bank untuk melakukan pembayaran kepada Eksportir, terhadap presentasi dokumen yang sesuai. Untuk itu sebelum membuka L/C, issuing Bank harus memastikan bahwa nasabah/debitur memiliki kemampuan untuk melaksanakan pembayaran pada saat kewajiban nasabah telah jatuh tempo.
\end{abstract}

Kata Kunci : Kredit, Bank, Letter of Credit

\section{AAbstract}

Credit or financing based on sharia principles provided by banks carries risks, so in practice banks must pay attention to the principles of credit or financing based on sound Sharia Principles. As an intermediary institution and in line with the external and internal environment of the banking system, it is currently experiencing rapid development. Banks are required to be more flexible in providing financing / credit by accepting guarantees that will still exist in the future. One of them is through credit / financing activities based on sharia principles through instruments known in international trade transactions is a Letter of Credit ("L / C"). L / C is a guaranteed payment guarantee from the issuing Bank to make payment to the Exporter, for the presentation of the appropriate documents. For this reason, before opening an L / C, the issuing Bank must ensure that the customer / debtor has the ability to make payments when the customer's obligations have matured.

Keywords : Credit , Bank, Letter of Credit 


\section{PENDAHULUAN}

\subsection{Latar Belakang Masalah}

Kredit atau pembiayaan berdasarkan prinsip syariah yang diberikan oleh bank mengandung risiko, sehingga dalam pelaksanaannya bank harus memperhatikan asas-asas perkreditan atau pembiayaan berdasarkan prinsip syariah yang sehat. Untuk mengurangi risiko tersebut, jaminan pemberian kredit atau pembiayaan berdasarkan Prinsip Syariah dalam arti keyakinan atas kemampuan dan kesanggupan Nasabah Debitur untuk melunasi kewajibannya sesuai dengan yang diperjanjikan merupakan faktor penting yang harus diperhatikan oleh bank. ${ }^{1}$

Untuk memperoleh keyakinan tersebut, sebelum memberikan kredit atau pembiayaan berdasarkan prinsip syariah, bank harus melakukan penilaian yang seksama terhadap watak, kemampuan, modal, agunan, dan prospek usaha dari Nasabah Debitur.

Mengingat bahwa agunan sebagai salah satu unsur pemberian kredit atau pembiayaan berdasarkan prinsip syariah, maka apabila berdasarkan unsur-unsur lain telah dapat diperoleh keyakinan atas kemampuan Nasabah Debitur mengembalikan utangnya, agunan dapat

\footnotetext{
${ }^{1}$ Undang - Undang Republik Indonesia Nomor 10 tahun 1998 tentang perubahan Undang - Undang Republik Indonesia Nomor 7 tahun 1992 tentang Perbankan, Pasal 8 ayat (1),
}

hanya berupa barang, proyek, atau hak tagih yang dibiayai dengan kredit yang bersangkutan. Tanah yang kepemilikannya didasarkan pada hukum adat, yaitu tanah yang bukti kepemilikannya berupa girik, petuk, dan lain-lain yang sejenis dapat digunakan sebagai agunan. Bank tidak wajib meminta agunan berupa barang yang tidak berkaitan langsung dengan obyek yang dibiayai, yang lazim dikenal dengan agunan tambahan.

Sebagai lembaga intermediary dan seiring dengan situasi lingkungan eksternal dan internal perbankan, saat ini sedang mengalami perkembangan pesat. Bank akan selalu berhadapan dengan berbagai jenis risiko dengan tingkat kompleksitas yang beragam dan melekat pada kegiatan usahanya. Resiko dalam konteks perbankan merupakan suatu kejadian potensial,baik yang dapat diperkirakan (anticipated) maupun yang tidak dapat diperkirakan (unanticipated) yang berdampak negatif terhadap pendapatan dan permodalan bank. ${ }^{2}$

Dalam rangka memelihara dan meneruskan pembangunan yang berkesinambungan, para pelaku pembangunan baik pemerintah maupun masyarakat, baik perseorangan maupun badan hukum, memerlukan dana yang besar. Seiring dengan meningkatnya kegiatan pem-

\footnotetext{
${ }^{2}$ Adiwarman A. Karim, Bank Islam, Analisis Fiqh dan Keuangan, Edisi Keempat (Jakarta : PT. RajaGrafindo Persada, 2010), hlm 255
} 
bangunan, meningkat pula kebutuhan terhadap pendanaan, yang sebagian besar dana yang diperlukan untuk memenuhi kebutuhan tersebut diperoleh melalui kegiatan pinjam-meminjam baik berupa pemberian kredit maupun pembiayaan yang berdasarkan prinsip syariah.

Selama ini, kegiatan kredit atau pembiayaan berdasarkan prinsip syariah yang disertai dengan jaminan selalu menggunakan hak tanggungan atau hak jaminan yang telah diatur dalam Undangundang Nomor 4 Tahun 1996 tentang Hak Tanggungan yang merupakan pelaksanaan dari pasal 51 Undang-undang Nomor 5 Tahun 1960 tentang Undang-undang Pokok Agraria, dan sekaligus sebagai pengganti dari lembaga Hipotek atas tanah dan credietverband.

Disamping itu, hak jaminan lainnya yang banyak digunakan dewasa ini adalah Gadai, Hipotek selain tanah,dan Jaminan Fidusia. Undang-undang yang berkaitan dengan Jaminan Fidusia adalah pasal 15 Undang-undang Nomor 4 Tahun 1992 tentang Perumahan dan Pemukiman, yang menentukan bahwa rumah-rumah yang dibangun di atas tanah yang dimiliki oleh pihak lain dapat dibebani dengan Jaminan Fidusia. Selain itu, Undang-undang Nomor 16 tahun 1985 tentang Rumah Susun mengatur mengenai hak milik atas satuan rumah susun yang dapat dijadikan jaminan utang dengan dibebani fidusia, jika tanahnya tanah hak pakai atas tanah negara. $^{3}$

Lembaga Jaminan Fidusia memungkinkan kepada para Pemberi Fidusia untuk menguasai benda yang dijaminkan,untuk melakukan kegiatan usaha yang dibiayai dari pinjaman dengan, kekayaan benda bergerak yang berwujud dalam bentuk peralatan. Akan tetapi dalam perkembangan selanjutnya, benda yang menjadi obyek fidusia termasuk juga kekayaan benda bergerak yang tak berwujud, maupun benda tak bergerak. ${ }^{4}$

Undang-Undang Republik Indonesia Nomor : 42 Tahun 1999 tentang Jaminan Fidusia (UUJF), dimaksudkan untuk menampung kebutuhan masyarakat mengenai pengaturan Jaminan Fidusia sebagai salah satu sarana untuk membantu kegiatan usaha dan untuk memberikan kepastian hukum kepada para pihak yang berkepentingan.

Seiring dengan perkembangan zaman, Bank dituntut untuk lebih fleksibel dalam memberikan pembiayaan/kredit dengan menerima jaminan yang masih akan ada dikemudian hari. Salah satunya yaitu melalui kegiatan kredit / pembiayaan berdasarkan prinsip syariah lewat instrumen yang dikenal dalam transaksi perdangan internasional adalah Letter of Credit

\footnotetext{
3 Penjelasan Undang-Undang Republik Indonesia Nomor : 42 Tahun 1999 tentang Jaminan Fidusia ${ }^{4} \mathrm{Ibid}$
} 
("L/C"). L $\mathrm{L} / \mathrm{C}$ adalah suatu jaminan pembayaran yang pasti dari issuing Bank untuk melakukan pembayaran kepada Eksportir, terhadap presentasi dokumen yang sesuai. Untuk itu sebelum membuka $\mathrm{L} / \mathrm{C}$, issuing Bank harus memastikan bahwa nasabah/debitur memiliki kemampuan untuk melaksanakan pembayaran pada saat kewajiban nasabah telah jatuh tempo.

Dalam kenyataannya pada saat kewajiban nasabah dalam hal ini L/C -nya telah jatuh tempo sehingga harus melakukan pembayaran kepada eksportir melalui Advising Bank. Nasabah mungkin tidak memiliki kemampuan untuk memenuhi kewajibannya baik itu sesuatu yag diperkirakan dari awal, yaitu kondisi dimana sumber pembayaran nasabah berasal dari hasil penjualan barang tersebut atau berasal dari hasil produksi terhadap pembelian barang/mesin tersebut kepada pihak lain, maupun disebabkan hal lain yang tidak diperkirakan dari awal, seperti nasabah mengalami kesulitan dalam cash flow. Sedangkan issuing Bank sebagai pihak yang menjamin tetap memiliki kewajiban untuk melakukan pembayaran terlepas dari ada atau tidaknya dana nasabah untuk menjaga kredibilitas nasabah dan Bank (name risk).

Dalam hal jaminan yang diberikan oleh Nasabah berbentuk setoran tunai atau blokir rekening senilai L/C yang dibuka, maka untuk melakukan pembayaran atas transaksi tersebut diatas bank selaku issuing bank untuk mendebet jaminan Nasabah tersebut. Namun apabila setoran tunai atau blokir rekening yang dilakukan kurang dari nilai L/C atau jaminan yang diberikan dalam bentuk lain maka issuing bank akan mengalami kesulitan untuk melaksanakan kewajibannya tersebut.

Untuk menjembatani kesenjangan likuiditas Nasabah dikarenakan sumber penyelesaian kewajiban yang timbul dari penerbitan L/C, Bank dapat menerima agunan dari Nasabah berupa barang-barang / mesin yang dibeli berdasarkan L/C tersebut dengan menggunakan Perjanjian Pengikatan Jaminan Fidusia \& Kuasa ("PPJF"), penggunaan PPJF sendiri merupakan rekomendasi dari beberapa Notaris kepada bank yang dilakukan dalam rangka mengamankan bank untuk mengikat barang agunan Nasabah yang sifatnya masih akan ada dikemudian hari.

Dalam UUJF sendiri tidak mengatur tentang bagaimana cara mengikat barang secara fidusia yang akan ada dikemudian hari. UUJF hanya mengatur bahwa dimungkinkan para pihak (Pemberi Fidusia dan Penerima Fidusia) untuk memperjanjikan jaminan secara fidusia berupa obyek barang bergerak yang timbulnya di kemudian hari. ${ }^{5}$ 


\subsection{Perumusan Masalah}

Berdasarkan latarbelakang yang telah dipaparkan di atas, maka permasalahan yang akan diteliti dapat dirumuskan sebagai berikut :

1. Apakah merupakan suatu kekosongan norma hukum terkait metode perikatan menggunakan PPJF yang tidak diatur oleh Undang-Undang Jaminan Fidusia ?

2. Bagaimana akibat hukum atas perikatan jaminan dengan PPJF terhadap mesin yang masih dalam pemesanan menggunakan Letter of Credit?

\section{METODE PENELITIAN}

Metode penelitian yang digunakan dalam penulisan ini adalah metode penelitian hukum normatif atau metode penelitian hukum kepustakaan adalah metode atau cara yang dipergunakan di dalam penelitian hukum yang dilakukan dengan cara meneliti bahan pustaka yang ada. ${ }^{6}$ Tahapan pertama penelitian hukum normatif adalah penelitian yang ditujukan untuk mendapatkan hukum obyektif (norma hukum), yaitu dengan mengadakan penelitian terhadap masalah hukum. Tahapan kedua penelitian hukum normatif adalah penelitian yang ditujukan untuk

\footnotetext{
${ }^{6}$ Soerjono Soekanto dan Sri Mamudji, Penelitian Hukum Normatif Suatu Tinjauan Singkat, Cetakan ke - 11. (Jakarta : PT Raja Grafindo Persada, 2009), hal. 13-14
}

mendapatkan hukum subjektif (hak dan kewajiban). 7

Pendekatan Undang-undang dilakukan dengan menelaah semua UndangUndang dan regulasiyang bersangkut paut dengan isu hukum yang sedang ditangani. Bagi penelitian untuk kegiatan praktis, pendekatan ini membuka kesempatan untuk mempelajari konsistensi dan kesesuaian antara suatu undang-undang dan /UndangUndang Dasar atau antara regulasi dan undang-undang.

Hasil dari telaah tersebut merupakan suatu argumen untuk memecahkan isu yang dihadapi. Bagi penelitian untuk kegiatan akademis, peneliti perlu mencari ratio legis dan dasar ontologis lahirnya undangundang tersebut. Dengan mempelajari ratio legis dan ontologis suatu undang-undang, peneliti akan menangkap kandungan filosofi yang ada dibalik pembuatan undang-undang itu serta menyimpulkan apakah terdapat benturan filosofis antara undang-undang dengan isu yang dihadapi. ${ }^{8}$

7 Hardijan Rusli, "Metode Penelitian Hukum Normatif: Bagaimana?", Law Review Fakultas Hukum Universitas Pelita Harapan, Volume V No. 3 Tahun 2006, hal. 50

${ }^{8}$ Peter Mahmud Marzuki, Penelitian Hukum : Edisi Revisi, (Jakarta : Kencana, Cetakan ke-13, 2017), hlm 252 
HASIL DAN PEMBAHASAN

\subsection{Kekosongan Norma Hukum Terkait} Metode Perikatan Dengan Menggunakan PPJF Yang Tidak Diatur Oleh Undang-Undang Jaminan Fidusia

Istilah jaminan merupakan terjemahan dari Bahasa Belanda, yaitu zekerheid atau cautie. Zekerheid atau cautie mencakup secara umum cara-cara kreditur menjamin dipenuhinya tagihan, disamping pertanggung jawaban umum debitur terhadap barangnya. Sedangkan menurut Hartono Hadisoeprapto hukum jaminan merupakan "Sesuatu yang diberikan kepada kreditur untuk menimbulkan keyakinan bahwa debitur akan memenuhi kewajiban yang dapat dinilai dengan uang yang timbul dari suatu perikatan". 9

Jaminan merupakan mempunyai kedudukan dan manfaat yang menunjang dalam pembangunan perekonomian masyarakat. Oleh karena itu lembaga jaminan dapat memberikan manfaat bagi debitur dan kreditur, antara lain : terwujudnya keamanan terhadap transaksi dagang yang ditutup dan memberikan kepastian hukum bagi kreditur. ${ }^{10}$

Jaminan kebendaan mempunyai ciriciri "kebendaan" dalam arti memberikan

9 H. Salim HS,2004, "Perkembangan Hukum Jaminan di Indonesia", Jakarta, PT. Raja Grafindo Persada, hlm. 22

${ }^{10}$ Ibid, hlm. 28 hak mendahului di atas benda-benda tertentu dan mempunyai sifat melekat dan mengikuti benda yang bersangkutan. Pada dasarnya perjanjian kebendaan dapat dibedakan menjadi 2 macam, yaitu perjanjian pokok dan perjanjian assecoir. Perjanjian pokok merupakan perjanjian untuk mendapatkan fasilitas kredit dari lembaga perbankan atau lembaga keuangan non bank.

Jaminan menurut KUH Perdata dibagi dua, yaitu : (a) Jaminan Umum, dan (b) Jaminan Khusus. Jaminan Umum diatur dalam Pasal 1313 KUH Perdata yang menyatakan "Segala kebendaan si berhutang, baik yang bergerak maupun tidak bergerak, baik yang sudah ada maupun yang baru akan ada di kemudian hari menjadi tanggungan untuk segala perikatan perseorangan”. Sedangkan suatu Jaminan Khusus diberikan oleh undangundang untuk melindungi kepentingan kreditor. Jaminan Khusus dinilai lebih memberikan perlindungan bagi kreditor karena objek jaminannya jelas dan barang yang dijaminkan diikat dalam suatu Perjanjian Jaminan.

Oleh karenanya dalam praktek pemberian pembiayaan dengan jaminan berupa benda bergerak, senantiasa dicantumkan klausul yang bunyinya “....berikut barang-barang yang dikemudian 
hari akan dimiliki oleh debitur....".11 Berikut adalah definisi berkaitan dengan Fidusia yang digunakan dalam penelitian ini $:^{12}$

a. Fidusia adalah pengalihan hak kepemilikan suatu benda atas dasar kepercayaan dengan ketentuan bahwa benda yang hak kepemilikannya dialihkan tersebut tetap dalam penguasaan pemilik benda.

b. Jaminan Fidusia adalah hak jaminan atas benda bergerak baik yang berwujud maupun yang tidak berwujud dan benda tidak bergerak khususnya bangunan yang tidak dapat dibebani hak tanggungan sebagaimana dimaksud dalam Undang-undang Nomor 4 Tahun 1996 tentang Hak Tanggungan yang tetap berada dalam penguasaan Pemberi Fidusia,sebagai agunan bagi pelunasan utang tertentu, yang memberikan kedudukan yang diutamakan kepada Penerima Fidusia terhadap kreditor lainnya.

c. Benda adalah segala sesuatu yang dapat dimiliki dan dialihkan, baik yang berwujud maupun yang tidak berwujud, yang terdaftar maupun yang tidak terdaftar, yang bergerak maupun yang tak bergerak yang tidak dapat dibebani hak tanggungan atau hipotek.

\footnotetext{
${ }^{12}$ Undang - Undang Republik Indonesia Nomor : 42
} Tahun 1999 tentang Jaminan Fidusia, Pasal 1 d. Pemberi Fidusia adalah orang perseorangan atau korporasi pemilik Benda yang menjadi obyek Jaminan Fidusia.

e. Penerima Fidusia adalah orang perseorangan atau korporasi yang mempunyai piutang yang pembayarannya dijamin dengan Jaminan Fidusia.

f. Utang adalah kewajiban yang dinyatakan atau dapat dinyatakan dalam jumlah uang baik dalam mata uang Indonesia atau mata uang lainnya, baik secara langsung maupun kontinjen.

g. Kreditor adalah pihak yang mempunyai piutang karena perjanjian atau undangundang.

h. Debitor adalah pihak yang mempunyai utang karena perjanjian atau undangundang.

Jaminan Fidusia merupakan perjanjian ikutan dari suatu perjanjian pokok yang menimbulkan kewajiban bagi para pihak untuk memenuhi suatu prestasi. ${ }^{13}$ Walaupun didalam penjelasan UUJF tidak ada penjelasan mengenai arti perjanjian ikutan, namun dimungkinkan istilah tersebut tertuju pada istilah accessoir.

Adapun ciri perjanjian accessoir adalah, bahwa ada/lahirnya, berpindahnya ${ }^{13}$ Ibid, Pasal 4 
dan hapusnya bergantung kepada perikatan pokoknya, dengan konsekuensi dilunasinya perjanjian pokok yang dijamin dengan fidusia akan mengakhiri jaminan fidusia, seperti juga beralihnya perjanjian pokok kepada kreditor baru, akan berakibat turut beralihnya jaminan fidusia.

Walaupun dikategorikan dalam perjanjian accessoir, Akta Jaminan Fidusia wajib dibuat dihadapan Notaris. Hal ini sebagaimana tersebut dalam Pasal 5 UUJF bahwa "Pembebanan Benda dengan Jaminan Fidusia dibuat dengan akta notaris dalam bahasa Indonesia dan merupakan akta Jaminan Fidusia”.

Prosedur dalam pembebanan jaminan fidusia yang dibahas dalam penelitian ini adalah yang dilakukan dengan penyerahan jaminan dan pemberian kuasa yang didasarkan atas perjanjian pembiayaan yang telah dibuatnya. Secara jelasnya proses terjadinya fidusia menempuh beberapa fase, yaitu : ${ }^{14}$

1. Fase pertama berupa perjanjian obligatoir. Diantara pihak pemberi dan penerima fidusia dibedakan perjanjian, dimana ditentukan bahwa debitur meminjam sejumlah uang dengan janji akan menyerahkan hak miliknya secara fidusia sebagai jaminan kepada pemberi

14 Muhamad Djumhana, Hukum Perbankan di Indonesia,(Bandung: PT. Citra Aditya Bakti, 2000), hlm 32 kredit. Perjanjian ini bersifat konsensual, obligatoir.

2. Fase kedua merupakan perjanjian kebendaan, Isi perikatan itu adalah untuk memberi sesuatu, karena debitur menyerahkan suatu benda (secara constitutum possessorium) kepada kreditur.

3. Fase ketiga berupa perjanjian pinjam pakai (bruiklening), Diantara kedua pihak diadakan perjanjian, bahwa pemilik fidusia meminjam pakaikan hak miliknya yang telah berada di dalam kekuasaan pemberi fidusia, kepada penerima fidusia.

Letter of Credit (L/C) sebagaimana didefinisikan dalam UCP (Uniform Custom Practice) adalah suatu perjanjian, bagaimanapun dinamakan atau diuraikan yang bersifat Irrevocable dan karenanya merupakan janji pasti dari Bank untuk membayar presentasi yang sesuai.

Dengan demikian, Penerbitan L/C adalah penerbitan pernyataan oleh Bank atas permintaan Nasabah untuk keuntungan pihak lain (Beneficiary), yang oleh karenanya Bank mengikatkan diri untuk membayar kepada Beneficiary, apabila Beneficiary dapat memenuhi permintaan/persyaratan yang dinyatakan dalam L/C tersebut. Berikut adalah istilah dan definisi yang sering digunakan dalam $\mathrm{L} / \mathrm{C}$ : 
a. Advising Bank, adalah bank yang diminta oleh Issuing bank untuk menyampaikan L/C kepada Beneficiary.

b. Applicant (Pemohon), adalah pihak yang mengajukan permohonan untuk mendapatkan layanan Penerbitan L/C, yang dalam hal ini adalah Importer.

c. Beneficiary (Penerima), adalah pihak yang dituju (penerima keuntungan) dari L/C yang diterbitkan, yang dalam hal ini adalah Eksporter.

d. Correspondent Bank (Bank Koresponden) adalah bank lain yang berada di dalam negeri maupun luar negeri yang mempunyai hubungan korespondensi dengan Bank (misalnya dalam bentuk pertukaran kode SWIFT/RMA, Test Key, Trade Line Facilities).

e. Issuing Bank (Bank Penerbit), adalah bank yang bertindak sebagai Penerbit $\mathrm{L} / \mathrm{C}$,

f. Dokumen L/C, adalah dokumen yang dipersyaratkan dalam L/C seperti draft/wesel, invoice, packing list, bill of lading / airway bill, dan lain-lain.

g. Impor, adalah perdagangan dengan cara memasukkan barang dari luar daerah pabean Indonesia sesuai dengan ketentuan perundang-undangan yang berlaku.

h. ISBP, International Standard Banking Practice. Yaitu dokumen yang diterbitkan oleh International Chamber of Commerce (ICC) dan berisi tentang standar internasional pemeriksaan dokumen.

i. UCP, Uniform Custom Practice, yaitu dokumen yang diterbitkan oleh International Chamber of Commerce (ICC) dan berisi tentang pedoman umum perdagangan Internasional.

Didalam UUJF hanya mengatur bahwa pembebanan/pembuatan akta fidusia wajib dibuat dengan akta otentik. Namun tidak pernah melarang atau mengatur pembebanan/ pembuatan akta fidusia dilakukan melalui kuasa. Dengan adanya kekosongan hukum dalam UUJF inilah yang telah menyebabkan praktek mengadopsi ketentuan lastgeving dalam Buku III KUHPerdata untuk memenuhi inisiatifnya dalam pembuatan PPJF. Sehingga praktek berpendapat bahwa prinsip pemberian kuasa itu bebas bentuk dan dapat dilakukan untuk semua perbuatan hukum, dapat dijadikan dasar pembenar dalam pembuatan PPJF di bawah tangan. Adanya asas umum dalam hukum perdata, dimana selama tidak diatur maka itu boleh/dapat dilakukan juga telah mendukung pendapat praktek dalam hal pembuatan PPJF dibawah tangan. Bahkan doktrin juga mengajarkan apabila suatu perbuatan hukum diwajibkan bentuk tertentu, bentuk kuasanya tetap bebas 
sepanjang undang-undang untuk kuasa itu tidak menentukan lain. ${ }^{15}$

Berdasarkan

pertimbangan-

pertimbangan tersebut, kiranya logis apabila praktek berpendapat bahwa penggunaan PPJF dapat dilakukan dalam pembebanan/pembuatan akta fidusia, mengingat tidak ada satu ketentuan pun dalam UUJF yang melarang mengenai pembuatan PPJF. Namun sebelum membenarkan atau mengikuti pendapat praktek diatas, patut untuk dipertimbangkann bahwa jaminan fidusia adalah bagian dari jaminan kebendaan yang merupakan sub sistem dari hukum benda yang meletakan asas tertutup dan memaksa (dwingendrecht). ${ }^{16}$ Hal ini, tentu sangat bertolak belakang dengan lastgeving yang merupakan sub sistem dalam hukum kontrak yang meletakan asas terbuka dan pelengkap (aanvullendrecht). ${ }^{17}$ Sehingga semestinya, ketentuan lastgeving tidak dapat diadopsi begitu saja untuk mengisi ketiadaan pengaturan dalam sistem hukum benda. ${ }^{18}$ Prinsip bahwa ketentuan Buku III KUHPerdata tidak dapat diterapkan begitu

${ }^{15}$ Asser Van der Grinten dalam J Satrio, Hukum Jaminan Hak Jaminan Kebendaan Tanggungan Buku I, (Bandung : PT Citra Aditya Bhakti,1998), hlm 168.

16 Mariam Darus Badrulzaman, Sistem Hukum Benda Nasional, Bandung: Alumni,1994, hlm.4.

17 Ridwan Khairandy, Hukum Kontrak Indonesia Dalam Perspektif Perbandingan, Bagian Pertama,(Yogyakarta:UII Press, 2013), hlm. 1617.

${ }^{18}$ Sudikno Metrokusumo, Penemuan Hukum Sebuah Pengantar, Edisi revisi, (Yogyakarta:Cahaya Atma Pustaka, 2014), hlm.26 saja dalam sistem hukum benda ini juga dapat dilihat pada keberadaan perjanjian kebendaan. Dimana ketentuan perjanjian obligatoir dalam Buku III KUHPerdata tidak semua berlaku/dapat digunakan dalam perjanjian kebendaan. ${ }^{19}$

Dalam hal tidak adanya ketentuan yang mengatur mengenai penggunaan PPJF dalam pembebanan/pembuatan akta fidusia bukan berarti serta merta dapat diterapkan bahwa sesuatu yang tidak diatur itu boleh, akan tetapi harus dilihat secara kasuistis. Karena adakalanya pembuat Undangundang tidak sempat mengatur suatu perbuatan dalam undang undang tapi mengaturnya lebih lanjut dalam peraturan perundang undangan yang lain, adakalanya perbuatan yang belum diatur oleh pembuat undang undang itu belum terpikirkan oleh pembuat undang-undang, karena pada saat itu belum dirasakan mendesak untuk diatur atau tidak diduga akan terjadi kemudian. Oleh karena itu, untuk mengetahui apakah dapat atau tidaknya digunakan PPJF sebagai dasar pembebanan/pembuatan akta fidusia maka perlu untuk menemukan hukumnya, seseorang tidak dapat begitu saja mengatakan boleh, atau menetapkan bentuk tertentu hanya dengan dasar tidak ada ketentuan yang mengaturnya.

19 Van Brakel dan Pitlo dalam J. satrio, Hukum Perikatan, Perikatan yang lahir dari Perjanjian Buku I, Cetakan II, (Bandung :PT Citra Aditya Bhakti,2001), hlm.57-58. 
Apabila dalam suatu hal tertentu terjadi kekosongan hukum, ilmu hukum telah menyediakan beberapa metode yang dapat digunakan untuk menemukan hukum dalam keadaan mana undang-undang tidak mengaturnya yaitu, antara lain :

a. Argumentum Per Analogiam (analogi)

Apabila peraturan perundang-undangan terlalu sempit ruang lingkupnya, maka akan diperluas dengan metode argumentum per analogian. Dengan metode analogi ini maka kekosongan hukum akan diisi ketentuan yang berlaku pada peristiwa yang serupa, sejenis atau keadaan dimana undang-undang memperlakukan sama. (contoh : Jual beli menurut Pasal 1576 KUHPerdata tidak akan memutuskan hubungan sewa menyewa. Dalam hibah, tukar menukar dan sebagainya tidak mengatur secara khusus mengenai hal tersebut. Maka dengan metode analogi ketentuan dalam Pasal 1576 KUHPerdata dapat ditafsirkan secara luas untuk berlaku pada setiap peralihan hak milik, sehingga disini ketentuan dalam Pasal 1576 KUHPerdata juga berlaku terhadap hibah dan tukar-menukar).

b. Argumentum a Contrario

Dalam hal undang-undang tidak mengatur secara khusus, akan tetapi kebalikan dari peristiwa tersebut diatur oleh undang undang. Cara menemukan hukumnya ialah dengan pertimbangan bahwa apabila undang undang menetapkan hal-hal tertentu untuk peristiwa tertentu, maka peraturan itu terbatas pada peristiwa tertentu itu dan untuk peristiwa diluarnya berlaku kebalikannya. (misalnya : Tidak ada pasal-pasal dalam KUHPerdata yang menjelaskan mengenai apa yang dimaksud "sebab yang halal" pada Pasal 1320 KUHPerdata. Namun Pasal 1337 KUHPerdata mengatur tentang "sebab yang terlarang" yaitu sebab yang bertentangan dengan undang-undang, kesusilaan dan ketertiban umum. Dengan menafsirkan Pasal 1337 KUHPerdata secara a contrario, maka dapat diketahui bahwa sebab yang halal adalah sebab yang tidak bertentangan dengan undangundang kesusilaan, dan ketertiban umum).

Dengan telah mengetahui hukum jaminan kebendaan merupakan suatu sistem hukum, maka dapat dipahami bahwa undang-undang yang diciptakan sebagai bagian dari hukum jaminan kebendaan meliputi gadai (pand), hipotik, hak tanggungan dan jaminan fidusia bukanlah sekedar kumpulan peraturan-peraturan/ norma-norma yang berdiri sendiri. Melainkan masing-masing peraturan tersebut memiliki arti penting dalam kaitannya dengan peraturan-peraturan hukum jaminan kebendaan secara keseluruhan, yang 
dibangun diatas asas-asas tertib hukum jaminan untuk mencapai suatu tujuan. Oleh karena itu, untuk menyelesaikan persoalan dapat atau tidak digunakannya PPJF dalam pembebanan/pembuatan akta fidusia, dapat diselesaikan dengan menggunakan metode penemuan hukum Argumentum Per Analogian (analogi), yaitu dengan menganalogikan fidusia dengan jaminan kebendaan lainnya dalam suatu sistem hukum jaminan kebendaan.

Oleh karena itu, penggunaan PPJF untuk pembebanan/pembuatan akta fidusia juga dapat dibenarkan menurut sistem hukum jaminan, tentu dengan syarat bahwa bentuknya juga harus mengikuti bentuk kuasa yang dikenal dan memang diatur dalam hukum jaminan kebendaan, yaitu harus dituangkan dalam bentuk otentik. Sehingga penyimpangan akan bentuk kuasanya, akan mengakibatkan kebatalan terhadap PPJF tersebut. Ketentuan lastgeving dalam Buku III KUHPerdata tidak semua dapat diberlakukan/digunakan untuk pemberian kuasa dalam sistem hukum jaminan kebendaan. Penggunaan kata kuasa dalam hukum jaminan kebendaan hanya dimaksudkan untuk menunjukan bahwa dalam kuasa tersebut terdapat kewenangan.

\subsection{Akibat Hukum Atas Perikatan Jaminan Dengan PPJF Terhadap} Mesin Yang Masih Dalam Pemesanan Menggunakan Letter Of Credit

Didalam UUJF maupun PP No. 21 Tahun 2015 tidak diatur mengenai penggunaan SKMJF dalam kaitannya dengan penandatanganan Akta jaminan Fidusia. Berbeda dengan penggunaan Surat Kuasa Membebankan Hak Tanggungan (SKMHT) yang diatur dalam Undangundang nomor 4 Tahun 1996 tentang hak Tanggungan. Namun sehubungan dengan pelaksanaan dan isi perjanjiannya terhadap penggunaan SKMJF dapat disandarkan pada Asas Konsesualisme (syarat sah perjanjian sebagaimana tersebut dalam Pasal 1320 KUHPer) dan Asas Kebebasan berkontrak (Pasal 1338 KUHPer) bahwa setiap orang dapat mengadakan perjanjian, baik yang telah diatur dalam undangundang, maupun yang belum diatur dalam undang-undang.

Sehingga untuk menjaga kepentingan Bank/Kreditur atas resiko yang muncul dikemudian hari, maka Bank akan mengambil langkah preventif yaitu dengan mengikat komitmen Nasabah dengan dilakukannya penandatanganan Akta PPJF yang pada intinya Nasabah bersedia menyerahkan kepada Bank yang pada umumnya merupakan dokumen-dokumen pembelian Line Machine seperti Invoice Mesin, untuk selanjutnya dilakukan 
penandatanganan Akta Jaminan Fidusia oleh pihak Bank atas dasar PPJF.

Pemberian kuasa menjual tersebut perlu kajian yuridis lebih lanjut, sebab pemberian PPJF tersebut kurang tepat karena alasan-alasan antara lain :

1) Pembuatan akta PPJF sebagai instrument pemenuhan kewajiban Nasabah sangat beresiko karena merugikan Nasabah itu sendiri, mengingat dengan akta PPJF maka setiap saat Bank dapat menjual obyek yang tidak dijaminkan oleh Nasabah. Dengan demikian maka tidak ada perlindungan hukum bagi Nasabah untuk mempertahan haknya.

2) Perjanjian utang piutang termasuk didalamnya berkaitan dengan perjanjian jaminan yang akan ada dikemudian hari dalam hal ini adalah akta PPJF yang didalamnya memuat kuasa jual terhadap persediaan, mesin dan barang bergerak debitur lainnya yang tidak disebutkan secara spesifik dalam akta PPJF bertentangan dengan asas spesialitas dan asas publisitas dimana benda jaminan harus jelas obyek perikatannya dan dilakukan secara sukarela. Sehingga pengikatan jaminan yang akad ada dikemudian hari akibat dalam transaksi LC dengan menggunakan PPJF semacam ini berpotensi merugikan kedua belah pihak dan batal demi hukum.
3) Apabila Nasabah wanprestasi, maka Bank berdasarkan klausul kuasa jual yang ada dalam PPJF akan mencari dan menjual obyek selain jaminan tersebut untuk mengambil pelunasan piutangnya. Dalam konteks ini kuasa yang diberikan seperti kuasa mutlak yang tidak dapat ditarik kembali oleh si pemberi kuasa.

Dari beberapa uraian mengenai penggunaan PPJF diatas, menunjukkan bahwa Akta PPJF yang dipakai oleh para pihak berpotensi merugikan salah satu pihak. Pihak Nasabah/debitur dapat dirugikan jika jaminan yang berupa Line Machine tersebut menjadi beralih haknya walaupun setelah dilakukan restrukturisasi pembiayaan debitur tidak wanprestasi.

Munculnya perjanjian pemberian kuasa tentu saja membawa suatu konsekuensi logis terhadap dunia hukum, yang sangat dibutuhkan dalam kehidupan masyarakat untuk memudahkan seseorang untuk melakukan hak dan kewajibannya yang karena keterbatasan waktu, jarak, dan alasan-alasan lainya tidak dapat dilakukannya sendiri. Sehingga demi terciptanya kepastian dan perlindungan hukum bagi para pihak yang terlibat dalam perjanjian pemberian kuasa tersebut diperlukan suatu pranata hukum yang memadai untuk mengatur perjanjian pemberian kuasa tersebut 


\section{KESIMPULAN}

1. UUJF hanya mengatur bahwa pembebanan/pembuatan akta fidusia wajib dibuat dengan akta otentik. Namun tidak pernah melarang atau mengatur pembebanan/ pembuatan akta fidusia dilakukan melalui kuasa. Dengan adanya kekosongan hukum dalam UUJF inilah yang telah menyebabkan praktek mengadopsi ketentuan lastgeving dalam Buku III KUHPerdata untuk memenuhi inisiatifnya dalam pembuatan PPJF. Sehingga praktek berpendapat bahwa prinsip pemberian kuasa itu bebas bentuk dan dapat dilakukan untuk semua perbuatan hukum, dapat dijadikan dasar pembenar dalam pembuatan PPJF di bawah tangan. Adanya asas umum dalam hukum perdata, dimana selama tidak diatur maka itu boleh/dapat dilakukan juga telah mendukung pendapat praktek dalam hal pembuatan PPJF dibawah tangan. Bahkan doktrin juga mengajarkan apabila suatu perbuatan hukum diwajibkan bentuk tertentu, bentuk kuasanya tetap bebas sepanjang undang-undang untuk kuasa itu tidak menentukan lain.

2. Karena tidak diatur oleh undang-undang maka isi dari akta PPJF ini tidak seragam, antara notaris tidak ada yang sama karena disesuaikan dengan kebiasaan, pengetahuan dan pengalaman Notaris. Sehingga opsi ini tidak mutlak bisa dijalankan, karena sifatnya merupakan terobosan hukum yang tidak diatur dalam UUJF, oleh karenanya tidak semua Notaris berkenan menjalankannya. Adapun berkaitan dengan penggunaan dari PPJF ini berpotensi dapat merugikan salah satu pihak dan pada saat Nasabah/Debitur wanprestasi, Bank berdasarkan PPJF tersebut memiliki akses dan dapat menuntut ganti kerugian dengan cara menjual semua benda bergerak, persedian dan mesinmesin lain yang dimiliki oleh Nasabah sebagai pelunasan hutang Nasabah/Debitur.

\section{DAFTAR PUSTAKA}

\section{Buku}

Adiwarman A. Karim, Bank Islam, Analisis Fiqh dan Keuangan, Edisi Keempat (Jakarta : PT. Raja Grafindo Persada, 2010)

Asser Van der Grinten dalam J Satrio, Hukum Jaminan Hak Jaminan Kebendaan Tanggungan Buku I, (Bandung : PT. Citra Aditya Bhakti,1998). 
H. Tan Kamello, Hukum Jaminan Fidusia:

Suatu Kebutuhan Yang Didambakan,

Bandung: Alumni, 2014.

Indra Soewarso, Aspek Jaminan Kredit, Jakarta: Institut Bankir Indonesia, 2002

Muhamad Djumhana, Hukum Perbankan di Indonesia,(Bandung: PT. Citra Aditya Bakti, 2000).

Mariam Darus Badrulzaman, Sistem Hukum Benda Nasional, Bandung: Alumni,1994,

Peter Mahmud Marzuki, Penelitian Hukum

: Edisi Revisi, (Jakarta : Kencana, Cetakan ke-13, 2017),

Ridwan Khairandy, Hukum Kontrak Indonesia Dalam Perspektif Perbandingan, Bagian Pertama,(Yogyakarta: UII Press, 2013).

Soerjono Soekanto dan Sri Mamudji, Penelitian Hukum Normatif Suatu Tinjauan Singkat, Cetakan ke -11 . (Jakarta : PT Raja Grafindo Persada, 2009).
Sudikno Metrokusumo, Penemuan Hukum Sebuah Pengantar, Edisi revisi, Yogyakarta: Cahaya Atma Pustaka, 2014.

Van Brakel dan Pitlo dalam J. satrio, Hukum Perikatan, Perikatan yang lahir dari Perjanjian Buku I, Cetakan II, Bandung : PT Citra Aditya Bhakti, 2001.

\section{$\underline{\text { Jurnal }}$}

Hardijan Rusli, "Metode Penelitian Hukum Normatif: Bagaimana?", Law Review Fakultas Hukum Universitas Pelita Harapan, Volume V No. 3 Tahun 2006.

Henry Donald Lbn. Toruan, Problematika Implementasi Pembiayaan Dengan Perjanjian Jaminan Fidusia, Jurnal Penelitian Hukum "De Jure", ISSN 1410-5632 Vol. 18 No. 2, Juni 2018: $183-204$

\section{Perundang-undangan}

Kitab Undang - Undang Hukum Perdata

Uniform Custom Practice (UCP)

Undang-Undang Republik Indonesia Nomor 10 tahun 1998 tentang perubahan Undang-Undang Republik Indonesia Nomor 7 tahun 1992 tentang Perbankan. 
Undang-Undang Republik Indonesia

Nomor 42 Tahun 1999 tentang

Jaminan Fidusia

Undang-Undang Republik Indonesia Nomor 21 Tahun 2008 tentang Perbankan Syariah

Peraturan Pemerintah Republik Indonesia Nomor 21 Tahun 2015 tentang Tata Cara Pendaftaran Jaminan Fidusia Dan Biaya Pembuatan Akta Jaminan Fidusia.

\section{BIODATA SINGKAT PENULIS}

Agus Andrianto, lahir di Bojonergoro, 2008-1982. Menyelesaikan pendidikan S1 Ilmu Ekonomi Fakultas Ekonomi, Universitas Airlangga tahun 2008. Pada saat ini sedang menyelesaikan program Magister Hukum pada Universitas Narotama Surabaya. 